\title{
Populist Rightwing Ideological Exposition: Netanyahu's Regime as a Case in Point
}

\author{
Gayil Talshir \\ Center for Advanced Public Policy, Department of Political Science, The Hebrew University of Jerusalem, Jerusalem, Israel \\ Email: gayil.talshir@mail.huji.ac.il
}

How to cite this paper: Talshir, G. (2018) Populist Rightwing Ideological Exposition: Netanyahu's Regime as a Case in Point. Advances in Applied Sociology, 8, 329-349. https://doi.org/10.4236/aasoci.2018.84019

Received: December 27, 2017

Accepted: April 22, 2018

Published: April 25, 2018

Copyright $\odot 2018$ by author and Scientific Research Publishing Inc. This work is licensed under the Creative Commons Attribution International License (CC BY 4.0).

http://creativecommons.org/licenses/by/4.0/

\begin{abstract}
Populism is often described as a thin-centered ideology, an underdeveloped worldview which can be found both on the extreme right and radical left, in authoritarian and democratic regimes alike. This paper goes against the grain arguing that rightwing populism of the dominant conservative party in established democracies developed a fully-fledged ideology which is irreducible to the quest for power or the desire to rule. Crucially, it encompasses a distinct notion of democracy which is hostile to rights-based theory yet forwards a discourse which is discernible and unique, reinterpreting the will of the people and majority rule. It further mixes neoliberal economics-cum-politics with neo-conservative nationalism and upholds a particular idea of the people and the state. Crucially, it forwards a concept of governability which centers on the government as the bearer of sovereignty encroaching upon the role of the parliament, courts and the gate-keepers, including the public media. This paper analyzes the 2015 Israeli election as a case in point. Ideological analysis, we argue, can explain for example why the most inciting government against the Arab Israeli citizens has also put forward the most radical 5 years plan for economic rehabilitation of non-Jewish minorities. The tension between neo-conservatism and neoliberalism shapes this domain. While national nuances are crucial, they still function as an ideological family so that a great deal can be learnt from one exemplar to the other.
\end{abstract}

\section{Keywords}

Political Ideology, Populism, Governability, Rule of the People, Israeli Politics

\section{Analytical Framework}

1) Conceptual Introduction.

Populism is usually analyzed as an integral part of authoritarian regimes or as 
a fundamental feature of the extreme rightwing in democracies (Freeden, 1996; Mudde, 2007). However, when populist authoritarians become leaders of dominant parties and rise to rule democratic states, this phenomenon can no longer hide in the shades of marginal, extreme politics. Kellner (2016) argues that "Trump is an authoritarian populist in the traditions of Ronald Reagan and Margaret Thatcher... Trump does not share the conservative ideology of Reagan and Thatcher, although he shares their electoral strategy of taking a populist pose claiming to represent the people against the political establishment" (Kellner, 2016: p. 20). Kellner further argues that like the Tea Party in the Republican Party, Trump believes in anti-government, anti-immigration, and pro-police, military, and hard-right law and order policies, but professes no clear ideology. Is that indeed the case? What is a populist republican ideology and how is it different from the new right of the 1980s?

For Mudde, populism essentially means the antagonism between the "pure people" and "the corrupt elite" whereby the people's will is more important than human rights or constitutional guarantees (Mudde, 2007: p. 23). The three core concepts of populism as a thin-centered ideology are nativism, authoritarianism and populism. But why is it a thin-centered ideology? Is it because it is versatile, and can be a left or right, authoritarian or democratic ideology? Or is it thin because it is inherently hollowed-out ideology, with a desire for power dominating the actors more than a robust worldview? Or is populism but a manifestation of Laclau's description of it as an empty signifier?

This paper suggests that populist rightwing ideology of the dominant conservative party in established democracies developed an ideology which is irreducible to the quest of power or the desire to rule. Crucially, there is a distinct notion of majoritarian democracy which is hostile to rights-based theory yet forwards a discourse which is discernible and unique, mixing neoliberal economics with neo-conservative nationalism and upholding a particular idea of the people and the state. While national nuances are telling, it is still an ideological family with family resemblance and ideological core which migrates across cultures and states.

In order to demonstrate this claim, the paper offers an analysis of the ideology of Netanyahu's regime in Israel. Unlike Trump, Netanyahu's ideology has evolved over time and was shaped by historical contingencies, social processes and political experience. It matured over three decades and had time to ripen. Its ideologues have progressed from the backbenchers of his Likud party and other rightwing parties, ten years ago, into top governmental positions turning ideas into policies. The key feature of this ideology, I shall argue, is the attempt to change the rules of the democratic game itself, not just to play by them. The key concepts are peoplehood and governability, revealing a limited concept of democracy which is based on the people rather than individuals, as well as neo-liberalism and neo-conservatism, despite the tension between these concepts. 


\section{2) Theoretical Setting.}

Ideology, arguably, is applied philosophy by nature. If philosophy deals with normative sets of values, ideology situates these values within a specific political setting thus shaping ideas by practice and ruling. But didn't Bell declare "the End of Ideology" already in 1960 (Bell, 1960)? The classic approach to analyzing party system change in democracies is based on electoral and sociological factors. Whereas Downs (1957) proposed an electoral battle on the median voter, Lipset \& Rokkan (1967) analyzed the social cleavages which are reflected in the party system and voters' alignments. Both theories assume the existence of an ideological axis on which parties compete in elections. Or, in Thomassen's words: “a basic condition for party democracy is that their party preferences are manifested and represented on one ideological axis" (Thomassen, 1994). This is the right-left axis that proved throughout the years resilient to the rise of new political issues and flexible enough to become relevant time and again (Smith, 1990). However, Mair argued that the poignancy of the ideological axis has weakening over the last generation and it is therefore less productive in explaining differences between parties (Mair, 2013: pp. 65-73). Thus, in the context of party system change, ideological analysis is contested. The dealignment school argues that today processes that connect voters to parties to government are weakening, as shown by decreasing levels of turnout, high volatility rates, the rise of the cartel party, personification, issue-based politics and the de-ideologization of the party system (Dalton \& Wattenberg, 2000; Norris, 2010; Mair, 2013). Analyzing the emerging ideology of the conservative heartland therefore goes against the grain, arguing that ideological evolution proves the viability of the party system and the fruitfulness of using the analysis of worldviews as part of explainable party system change. Ideological transformation thus proves crucial in actually demonstrating the viability and adaptability of advanced democracies. A crucial issue for the discussion would therefore be, whether an illiberal version of conservative ideology, with strong perception of majoritarian rule and collective rights, is indeed strengthening democracy or actually weakening the legitimacy of the democratic framework.

\section{3) The Israeli Case.}

Thomassen (1994) insists party democracies are characterized by one dominant Left-Right axis on which all parties positions can be aligned. Whereas in other democracies Left-Right traditionally translates into economic positions, in Israel the dominant cleavage since 1967 is the solution to the Israeli-Palestinian conflict, between the two states solution on the Left and annexation of the occupied territories on the Right. The change of power in 1977 is recognized as the watershed of Israeli politics. However, in the 2000s processes of dealignment prevailed. Dealignment became the dominant thesis, based on growing fragmentation, personification, volatility and de-ideologization processes, so much so, that political processes in general and elections in particular are harder and harder to predict and understand (Arian et al., 2006; Shamir et al., 2008). In order to challenge this thesis of dealignment, we strive to demonstrate that the 
major ruling party of Israel—the Likud party-and its "natural partners" as Netanyahu calls the religious, ultraorthodox and nationalist parties that share his coalition governments, developed a distinct ideology with clear profile which differs from its historical predecessor-the Herut (Liberty) Party.

One fascinating reaction to these processes was the emergence, side by side with the Israeli-Palestinian conflict axis, of two other dimensions. In the aftermath of the 2011 social protest, economic issues gained salience and were reinforced with both Yesh Atid and Kulanu rising as new parties to accommodate the cost of living and housing as their main concerns and leading the 2013 and 2015 elections on economic issues respectively. The economic axis thus became prominent in Israeli politics. The third axis usually analyzed is state/religion relations. This axis is prevalent in Israeli politics both because of the tension between Jewish as religion vs. as nationality, in determining the character of Israeli democracy, but not least because of the unique position of the religious parties as pivotal parties which align on this axis thus refrain from the traditional Left or Right characterization on the other axes (Diskin, 2004). However, as of 2013 the major debate in which religion/state is just a part of, is the debate over the common vision of Israel, the debate on the nature of Israeli democracy: Jewish or Israeli, democracy or ethnocracy (Shamir \& Arian, 1999; Talshir, 2015). While state/religion was a sectorial issue of the religious parties, the Jewish/democratic collective identity axis is an ideological axis which defines-and distinguishes-all the parties. In fact, it became the major battlefield of the 2015 elections (Shamir et al., 2017).

4) The Structure of the Argument.

In order to expose the ideology of Netanyahu's government we take three case studies which represent each of the three ideological dimensions in Israeli politics-the Arab-Israeli conflict, the socio-economic sphere and collective identity realm. For each of these cases a discursive analysis and conceptual morphology would be made, to account for the key notions as well as dominant processes which characterize the government (Van Dijk, 2011). These concepts and processes then serve to profile the Netanyahu coalition government ideology, using a conceptual analysis (Freeden, 1996).

5) Methodology: Case-Study-Embedded Conceptual Analysis.

Applied social science may also instruct us in the choice of methodology. One option for ideological analysis is a study of discourse and pure conceptual analysis analyzing speeches and manifestoes. In this paper, applied social analysis means working with compound case studies to discern the ideological evolution and its shaping as spheres for discursive and conceptual analysis. Working with the three dominant axes of Israeli politics-Arab-Israeli conflict, economic axis and collective political identity-serves as the benchmark for deciphering the ideological evolution. Three demonstrative cases are chosen, one for each ideological axis, trying to analyze not just what is the government's ideology-cum-policy, but how it is, crucially, trying to change the rules of the game. While the political analysis distinguished between political, economic and identity axes, the case 
studies at hand would prove the inner-tensions but also the interconnections as we move from one axis to another.

In terms of methodology therefore, the paper introduces three cases-each for an ideological dimension-as way of exposing the ideological core of the Netanyahu regime. The key issue which traditionally determined the Israeli election, 2015 notwithstanding, was the security-cum-identity issue (Shamir et al., 2017: pp. 61-62). A crucial topic was the way Netanyahu portrayed the Palestinian-Israelis in his speeches and on "facebook". The relation to the Arab citizens of Israel is the first case study. On the economic axis one of the crucial processes led by the Netanyahu government was the abolition of the Israeli Public Broadcast. It was constructed as a neoliberal reform in the 2013-15 government, and was dramatically changed to become a governability issue in the $34^{\text {th }}$ government. It shows the complexity of working with neoliberal economics convictions side by side neoconservative beliefs and therefore was chosen as the second case. The third case, for the collective identity axis, is the National Home Basic Law which demonstrates the progression and evolution of the Netanyahu doctrine-and exposes some of the crucial ideologues of this line-Shaked, Levin and Elkin. Through these cases a discourse analysis from which the core concepts of the rightwing government, is performed, showing the core, the periphery and those concepts that are not in the orbit of Netanyahu's ideology (Freeden, 1996). Most interesting in this regard is the struggle for democracy as a contested concept-whether the majoritarian democracy interpretation of the government, given its attack on civil rights organizations and the judicial system for example, still qualify as a legitimate-albeit ground-changing-concept of democracy.

\section{Populist Republicanism-Politics, Economics, Identity-Case Studies Analyzed}

1) Palestinian-Israeli Conflict or (Fundamental) Islamism-Judaism? Changing the Terms of Public Discourse.

The first case is the relation of Netanyahu and his campaign headquarters to the Israeli Arabs in the very final days before the elections, and its aftermath. 2015 Israeli elections were primarily on the possibility of political change, shifting the ruling power from Netanyahu's government to a center-Left coalition: the polls consistently gave advantage to the then Labor, now Zionist Camp, over its rival and ruling party-the Likud; V-15 was launched as a campaign of the Left to target relevant voters and the overall estimation was that the personal dissatisfaction from PM Netanyahu-the investigations, the Israeli Literature Prize, and the Israel Beitenu systemic corruption affair-would produce an anti-rightwing effect and cause the voters to stay at home, so that the rightwing turnout was expected to remain low. The Media concluded: a change of government may well be on its way (Shamir \& Rahat, 2017). The reaction of Netanyahu was to go back to the basic fears of the people: while other parties talked about the hope of change, the economy and the cost of living, Netanyahu talked 
about the threat from Iran and ISIS. In the very last days before the elections, when it was clear that the Right is in disadvantage, and that his own camp is fed up with the government's corruption and inaction, translated into low turnout, he launched a campaign which focused on the Arab vote in the Israeli elections in connection with the threat of terror and radical Islamization.

Here is what Prime Minister Netanyahu filmed and posted on his Facebook on the day of the 2015 election-when the traditional Media is no longer aloud to broadcast campaign; but social Media has no rules:

"The rule of the right is in danger. Arab voters are streaming in droves to polling stations. Leftist NGOs are bringing them in buses. We don't have a V-15 [activist group for the opposition], we have only a 'Tsav 8 ' [emergency military call-up]. We only have you. Go vote, bring friends and family, vote MAHAL and we'd close the gap with Labor. With your help and with God's help we'll establish a national government that will defend Israel.” (Oren, 2015).

This was filmed on the following background (Figure 1).

This, coupled with more than half a million SMS messages sent to targeted Likud voters in specific neighborhoods and towns with low turnout, in the last hours of the election, all dealing exclusively with the Arabs in Israel, reading "turnout is three times higher in the Arab sector" and "Hamas called the Israeli Palestinians to vote in the elections" or "residents of Beer Shiba-the Arabs are voting in masses don't let them determine the ministers in the next government"-messages some would call pure incitement against the Arabs (Oren, 2015), did the work. In the last two hours of the elections twice the number of voters went to vote, voting for the Likud (Segal, 2015; Caspit, 2018).

Let's pose on Netanyahu's post. Consider the background: Netanyahu is filmed with the map of the Middle East behind him, and the flag of Israel to his side. The image does its own work: he is talking about the Arab citizens of Israel, but invoking the Islamic world at large: Saudi with its connections to Al-Qaida, Egypt with the Arab Spring turning to Islamic revolution and the military takeover,

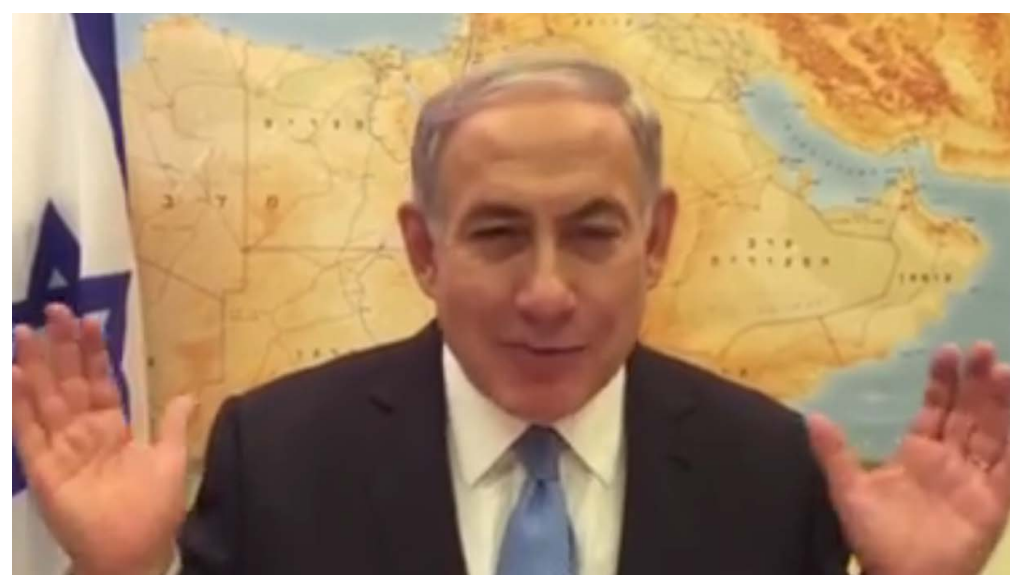

Figure 1. Netanyahu's 2015 election Facebook broadcast: Arab voters are streaming in droves to polling stations ${ }^{1}$.

'https://www.youtube.com/watch?v=Q2cUoglR 1yk (last checked 12 June 2017). 
Iran-supported Gaza with the Hamas rule, and the nuclear threat, Lebanon's Hezbollah and Syria and Iraq-two failed states with ISIS taking over parts of them. One hears about the Arabs in Israel but the visualization is of Islamic fundamentalism all around Israel. Netanyahu is portrayed as the sole savior of the Jewish State. Furthermore, Netanyahu erects a binary opposition-we vs. them, good vs. evil. On the evil side are the Arabs and V-15-what the PM tags consistently as 'radical leftwing organizations' which are supported by foreign European governments to aid Labor. These are human rights organizations and social movements. The delegitimization process is at work-the extreme left and the Islamists threaten the national government. They are anti-Zionists, and they are evil. But who is on the other side? On the other side of the normative divide are the "good guys" in his narrative: they don't have V-15 they have Tsav 8-the emergency military order: the IDF is on the good side, as is every voter going to vote for the right, as is God and Netanyahu. In his coalition-the IDF, God and the people. This is the bad vs. good, we vs. our enemy, equation.

Why are the Arab Israelis so crucial for Netanyahu's views of the Palestinian-Israeli conflict? After all, the Arab voters in Israel are, actually, a marginal force. Before 2015 the Arab vote is substantially lower than the Jewish turnout, and Arab voters were always divided into 3 different parties with no real power to influence any legislation or policy. The data given by Bibi's campaign is, of course, far from being accurate: the turnout of Arab Israelis in national elections is substantially lower than the Jews. By 18.30 on the election-day, the turnout in the Arab sector was identical to the 2013 elections-56\% only ${ }^{2}$. By the end of the day the turnout of the Arabs rose a bit in relation to the previous elections, but was still lower than the Jewish vote: in 2015 the general vote was $72.3 \%$ and the Arab vote $63.5 \%$.

So why are they made the centerpiece of Netanyahu's concern in the actual day of the election? Because in his argument they are being portrayed as a fifth column. They, and the Left that supports them, are traitors. They raised fear and colored the whole Left block with anti-patriotism. This last minute tactics worked. The campaign-managers-and the PM-stroke a cord. The SMSs targeted at voters in low turnout voting area-by the way the strategy of V-15 which failed for the Left-brought the victory to Netanyahu's government (Segal, 2015).

Ironically, the results of the elections looked like Netanyahu was right in his incitement: The Joint List of the Arab parties received 13 MKs and became the third largest party in the 20th Knesset. But perhaps the irony lies somewhere else: the unification of the Arab parties was instigated by what is called the "governability" argument. The 2013 Netanyahu's government decided to legislate a number of rules to raise the effectiveness of the government. Among them was the idea to raise the threshold from $2.5 \%$ to $4 \%$ (2013b). The main engine behind the change was Liberman, the now security minister, who holds a position that border changes should be carried out so that the Arab villages in the "triangle" ${ }^{2}$ http://www.maariv.co.il/news/elections-2015/Article-468498 (last checked 1.2.2018). 
area near Vaddy Arah would be part of the Palestinian authority, not Israel in the future.

Liberman hoped that raising the threshold from $2.5 \%$ to $4 \%$ would cause the Arab parties to not pass the threshold and disappear from the Israeli parliament. However, their reaction was to form an ad hoc alliance and run as a joint list without breaking their three parties. Hence, governability pushed for a change of which its unintended consequences were the largest ever Arab party in the Israeli Knesset.

Irony, however, does not stop here: the rightwing government that was established after that day's victory for the Likud, put forward the most profound economic plan for the Arab society in Israel that any government has ever passed (Finance, 2016). On 30 December 2015, half a year after the elections, proposal 922 titled "Governmental Activity for Economic Development of the Minority Populations in Israel" (2015), has passed the vote. It started as a professional committee which was ordered by the 2014 finance minister, also the then PM, Netanyahu himself. The program was made by the top governmental officials, led by the minister's deputy, head of budgeting department, Amir Levi, who analyzed systematically the reasons for the cleavages between the general Israeli public and the Arab minorities, mapping the major areas of disadvantages. The newcomer minister of finance of the 2015 government-Cakhlon, leader of $\mathrm{Ku}$ lanu, approved this direction. Casted as a 5 years plan of 15 billion shekels, it changed dramatically the budget set aside for the Arab local authorities and citizens. The crucial characteristic of this plan is that unlike many previous programs targeted at the Arab sector, 922 is not a special budget program set aside for a limited time, but a $20 \%$ allocation at the base of the annual national budget of central governmental ministries-education, housing, infrastructures, transportation etc. for investment in the Arab sector (Cohen, 2017). Whereas special plans for assisting Arab sector usually failed due to under-execution, and inability of the authorities to demand and channel the funds, this time the finance ministry worked systematically, with all the top civil servants in the relevant ministries, to devise a map from planning to activation, while cooperating with the Arab local authorities as partners. Furthermore, the Arab parliamentarians, who are usually very cautious about cooperating with the 'Zionist regime' were fully cooperative and worked together with the finance ministry to bring this plan about.

What is going on?

Some would say this is the back-and-forth Netanyahu's behavior-inciting on the election night, and apologizing the morning after ${ }^{3}$. Others would say that the one would have not happened without the other-that the direct assault on the Israeli Arab citizens received so much criticism that reconciliation had to happen. Yet, if one looks at the deeper ideological roots, observing the two sides of the paradox, one can recognize the fingerprints of two, coexisting yet contra${ }^{3}$ Netanyahu invited guests from the Arab and Druze sectors and said "I know my words insulted Israel's Arab population. I had no intention of doing that. I'm sorry.” See also (Oren, 2015). 
dicting rightwing ideological trends: neo-conservatism and neoliberalism.

On the one hand we find neo-conservatism, in its national, xenophobic, "we vs. them" manifestation: Arabs against Israelis, Muslims against Jews, the internal enemy, the fifth column against the state. On the other hand, the rationale behind the economic plan for the Arab society was driven by economic growth. The economic reality is that Arab women have only $33 \%$ rate of employment in Israel, in comparison to $71 \%$ of the Hebrew Israelis (despite the fact these are much higher rates than Arab women in Arab countries), and 75\% of the Arab men are employed, countered with $81 \%$ of the general male population (Myers-JDC-Brookdale, 2015). The economics tell a simple story: there is a tremendous economic gain in closing the gaps. Some of the gaps are due to governmental discriminatory policies and neglect, some due to the traditional Arab society with its norms and practices. Yet, from an economic growth perspective the picture is clear. One such example for economic transformation is the Druz population. Over the last decade the Druze community performed nothing less than a revolution in education-moving from very low matriculation rates to being at the top of Israeli society (Datal, 2015). The result of the Druze society investment in education, which has combined governmental funds with internal change of the community, had a clear impact on a crucial factor: the child birth dropped sharply from 7.5 in the 1960s to 2.2 children per family today (Datal, 2015). Educational and economic changes have social consequences.

Thus, there are two ideological streams that conflict within the Netanyahu government, the major actors of which could be seen in the support or rejection of the 922 proposal: Gamliel, Cakhlonand Dery supported the program. Levin, Elkin, Regev and Akunis were against. And the PM? While Netanyahu initiated the committee, he was resentful of the program. He was actually pushed by the finance ministry, president Rivlin and others to accept it. His reluctance, and the play between the two co-existing ideologies, can be seen in how Netanyahu sought to link the economic program with stringent measures against the illegal construction in the Arab villages. Two weeks after the program has passed 11 houses were destroyed in Kalansua and Um El-Chiran was to suffer the same destiny had it not been for a policeman that was killed in the riots against the obliteration of houses there (Cohen, 2017). In the end of the day the PM was pushed into accepting the economic plan, so he emphasized, in the public media, the linkage between law and order in the Arab villages and illegal construction and economic benefits.

So, politics and economics intertwine and nevertheless are found in a tensed relationship in rightwing ideology. The Arab minority are central part in any terror-related argument forwarded by the right as an anti-Left argument, and the ties between "radical Left" and the Arabs on the one hand, and "radical Left" and "foreign governments"-being part of the argument that the Left is unpatriotic and being aided by European states that harm Israeli sovereignty and influence its policy through extreme leftwing organizations-is a commonplace argument of the Netanyahu regime. The same "fifth column" non-Jewish minorities may 
hold the key to economic growth in Israeli economy which is why from a neoliberal perspective other rightwing politicians look favorably on the move towards investing in the Arab minorities. Netanyahu's old idea of "only he who gives would receive"-which he invented for the Palestinians, might end up being the approach that will characterize his attitude towards the Arab Israelis too. Needless to say, there is no symmetry as many of the construction violations that $\mathrm{Ne}$ tanyahu personally referred to and later tried to link together in the discussion of the economic plan, are due to the fact the Israeli governments rarely authorized construction plans, much less expansion plans, for the Arab sector.

But what is at work here, is also a change of the public discourse: The Israeli-Palestinian conflict, which was hardly part of the debate in 2015 election, re-entered through the backdoor of the Right vs. Left argument: here there is a two-edged move. First, the conflict is not just about the occupied territories as Palestinian terror is carried out both by Israeli Arabs and Palestinians from the territories-so there is Palestinianization of the Israeli citizens; second, these very same Arabs, Palestinians, are actually Muslims meaning maybe part of the fundamentalist ISIS movement in the Middle-East. And the ultimate neoconservative argument: these are the people to whom civil rights (leftist) organizations want to aid. It is their rights versus Jewish collective rights, and it is clear where does Jewish loyalty should reside. So, the political axis is actually being transformed into the collective identity axis, on which this election was actually fought (Shamir \& Rahat, 2017).

2) “It's the Economy Stupid?" Economics and Governability Intertwined.

One of the crucial internet Likud virtual campaign videos that became viral during the 2015 election presents the following scene: people are sitting in a circle imitating an AA meeting, each of them gets his turn, opening by the assertion "I am here because of Bibi" and after each participant's speech all the others reply "we love you X". Who is represented in this Likud campaign clip? A unionist from the seaport, a worker of the public Israeli broadcast service, working in the tax-collecting branch, a cellular company guy (who has a white tiger as a pet) and-a Hamas terrorist activist. When the others say "we love you Mustafa", the PM enters the room. "It is We or Them" reads the Likud slogan. Notice that all the motives that were already identified are here, at a very early stage of the campaign: the Left "loves" Arabs; all those who the public likes to hate are the enemies of the state, by endorsing Hamas terrorist; and Bibi "takes care" of all of them: a reform of the ports breaking the trade unions, a reform-turned-annihilation of the Israeli public broadcasting, the cellular reform-and Hamas, which only Bibi can deal with. The tactics of turning your ideological rivals into disloyal followers of the antipatriotic Left, is also at work here. But what is the ideology that connects the trade unions, the public broadcasting and the Hamas? Is it mere tactics with no deep underlining worldview that connect the dots between weakening the gatekeepers and fighting Hamas? "It's the economy, stupid" would be one such bridge: Netanyahu likes to see himself as Mr. Economy, and as long as the economy blooms and economic growth is high, the political sta- 
tus-quo is justified. However, my argument will be that his neoliberalism is linked to a very specific concept of governability, in which two contradicting logics coexist. I take the case of the abolition of the Israeli Public Broadcasting Authority (IPB) as a case in point.

Was the abolition of the IPB a done deed in Netanyahu's mind when this viral movie was made? Hard to tell. The tale of the execution of the watchdog of democracy-free and critical public media-has three major phases all of which fit the description embedded in the movie, despite the fact they are contradicting. The first phase is that of a reform. Reform, as the movie portrays, is a key concept in Netanyahu's ideology. As the finance minister he channeled a series of reforms which to his analysis changed the face of Israeli economy for ever-for the better (Simchon, 2016). In 2013 the most notable reform was that of the cellular market-led by the then communication minister Cakhlon-which managed to raise the competition and save Israelis on their monthly cellular budget. Netanyahu famously called in the post-social-protest 2013 election to his Likud ministers "you should all be Cakhlons". The plan to abolish of the IPB and with it the tax-was certainly conceived within the context of neoliberal reforms-the Netanyahu hardcore economic ideological blueprint.

Importantly, a modest reform plan was already ready for implementation, awaiting only the signature of the incoming minister of communication that Netanyahu has appointed by 2013-Ardan - to be added. This reform was the result of long negotiations between the PBI different unions, some 16 different organizations representing the workers, the finance ministry officials who led the process and the PM office. Ironically, the trigger for the initial reform were reports of the comptroller which concerned the corrupted manners of the IPB, due to the political unprofessional leadership of the organization-which was appointed by the PM's representatives, with their direct involvement in some of the programs and beneficiaries (Comptroller, 2011). However, Ardan, the new minister, did not sign the ready-made reform. "Be Cakhlons" said Netanyahu-and Ardan played exactly this role: he was to be the minister who will put an end to the hated IPB tax, the execution branch of which hustled thousands of Israelis who declined to pay the fees. But Ardan, a good student of his leader, whose slogan was always "cut down on the fat man", i.e. the civil service, sought to do even better: not just to cancel the tax, but to take the PBI out of the government orbit of influence and into the professional, economically effective realm.

The Landes Committee, which Ardan appointed with the support of Netanyahu, included professionals from the finance market and the Media as its members. It was very clear in its recommendations: close down the PBI; establish a new, professional body, with a council led by a judge that will be much leaner on the budget and professional in its behavior, distancing it from politicians and the bad political culture of the PBI (Landes, 2014). Ardan, the loyal minister of communication appointed by Netanyahu, and the finance minister Lapid, endorsed the report as did Netanyahu himself. Again, the new policy line was ready for implementation. A new authority was established and phasing-out 
of the IPB has begun.

But then came the 2015 election. The coalition agreement on which all coalition partners had to sign had a very peculiar article 26 in it which states that the government would lead major reforms in the communication market, all the coalition partners commit to support these reforms, as well as to abstain from supporting any initiative in the realm of communication without the expressed consent of the communication minister. All coalition parties and members will oppose any initiative that the communication minister would oppose to ${ }^{4}$. Firing Ardan abruptly just before the conclusion of the Landesre form, the new minister of communication, appointed by Netanyahu-was no other than PM Netanyahu himself. Why put into the coalition agreement such a clause? Obviously, because Netanyahu knew his new moves would generate opposition even within the coalition: both Ardan, who was surprised to discover that his tailor-made elegant closing-down-opening-up reform, which followed closely everything for which Netanyahu as a finance minister stood for, was to be reversed, and Cakhlon, who is to be the new finance minister and the only semi-center to the left of the most rightwing coalition Israel has ever had. Other, not less dramatic structural changes with the telephone market and the monopoly of Bezeq on it, where also to be supervised by Netanyahu and his confidant, now CEO of the Communication ministry-Filber. The damming testimony of Filber would be crucial in the Netanyahu investigations that were exposed in February 2018.

What was going on back in 2015? Why the strategic move to close down the IPB was now turned on its head as Bittan, head of the coalition and Netanyahu's executer, proposed to reconsider and adopt the former reform which Ardan rejected back in 2013, instead of going with the new platform which Netanyahu supported in the last Knesset? The heads of the new authority are Leftists, disclosed Bittan (Toker, 2017b). And Regev, the minister of culture, said in the ministers' committee of legislation on 31 July 2016:

What's the value of the (new) authority if we don't control it? The minister has to rule. What, we give money and then they will broadcast whatever they want? (Malki, 2016).

Why was the new authority, Kan, rejected by the loyal ministers of Netanyahu? Omer, the chairman of Kan, disclosed in the parliamentary committee that politicians pressured the new management of Kan to appoint their people, while Ben-Rubi, the new manager of the news radio station at Kan urged the politicians to admit that they do not want public authority broadcasting at all (Toker, 2017b). Indeed, on November 2017 Dery, who received unsympathetic attention regarding the police investigations in his case, put forward to the government the idea to close down all the new authority of public broadcast and leave just the news radio (Toker \& Zecharia, 2017). The new communication minister, that Netanyahu was forced by the courts to appoint as his replacement, imme${ }^{4}$ For example, see (2016) Coalition Agreement for the Establishment of the 34rd Government of the State of Israel between the Likud and Israel Beytenu. 
diately twitted that it is a good move which will save the public on taxes. The minister stroke down this twit immediately after its release: his master has not yet approved, even though it was the idea of the CEO, appointed by Netanyahu and today under investigation and a state-witness-Filber-to close down the new authority should the move to regain control of it failed. In any case, this new appointment of the minister-Kara-a Druze, and the first non-Jewish minister in Israel ever-was ordered by the court since Netanyahu is under investigation regarding the alleged connection he has with the editor of Yediot Achronot newspaper, allegedly trading more positive coverage of the PM for reduction in the copies and cancellation of the weekend edition of the free newspaper Israel Today which is being given for free, and is being owned by Netanyahu's friend Sheldon Adelson.

Incidentally, this free newspaper was the reason why Freedom House lowered Israel's democracy status due to threat to free speech in 2015. The democratic state of Israel is harmed by the government's policies and actions. Public Media and democracy go hand in hand. But of course, not just the PBI and the written newspapers were being transformed: the government authorized a new, rightwing traditionalist TV channel 20. First, it was supposed to be a traditionalist cultural channel, but gradually it began to broadcast news, first in an unauthorized manner and then by a law that the coalition under Netanyahu has passed, so it became gradually the exclusive TV channel for which the PM gives interviews. This very channel won the auction to run the Knesset channel, which the supreme-court suspended and reviewed. On 22 February 2018, the supreme-court decided to return it back to the committee for reconsideration. Netanyahu's passion to control the Media, but at the same time to attack it, has many more dimensions than were brought here (Toker, 2018).

But how did the PBI saga developed? By a new governmental law which orders the establishment of a new news agency which would detach Kan from all its news-coverage role. A hasty decision was passed by the Knesset to divide the new Kan authority into two separate organizations, so that the news authority would be completely out of reach of the Kan management, with a new council and chairperson. This law ended up in the supreme-court which gave, on November 6, 2017, the state two weeks to reply whether it is going to amend this law or just cancel it, before the court gives its ruling. Judge Meltzer said that "there is no such model in any of the western democracies. It is impossible and impractical and therefore does not exist" (Toker, 2017a). The government replied that the amendment was lawful and lawfully submitted. The court now has to provide its ruling. Should the court decide to overrule the coalition's hasty law, this will only serve as a vindication of the main argument of the Netanyahu government: that the courts are one-sided and get involved politically instead of being impartial judges. It goes back to politics of identity, and the accusation of "everything being politics" which is what president Rivlin said in the opening of the 2017 fall Knesset session: 
The Israeli Media can be criticized... but it is one thing to try to fix it... quite another to want to control it. Tell me how does a weak Media that begs for its life could be in the interest of Israel or of Israeli democracy? ... Where are we going to? Is this governability? ... There is no longer statehood only governability. Democracy in such an atmosphere means that the strong rules. The power of the occasional majority is what governs (Rivlin, 2017).

The president argues that the gist of this coup d'état is to weaken the gatekeepers of Israeli democracy, with whom he counts the judicial system, top bureaucracy, the attorney general and law enforcing forces side by side with the public Media. If so, what is this concept of governability, which according to the president abolishes statehood and brings about an "all is political" revolution-which amounts to a de facto tyranny of the majority? The ideologues in Netanyahu's government forward to following argument: the ministers represent the people who are the sole authority in democracies. The ministers, trying to implement their worldview through devising policies, are being opposed by the bureaucrats in their ministries, by the state attorneys, and by the courts, none of whom was elected by the people, and therefore lack any legitimacy but obfuscate the people's democracy. Hence the attempts to politicize the management of the ministries, to weaken the attorney general, to reduce the power of the courts and to curtail the critic of the public media. This concept of governability seeks to transfer the rules of the game, not just to play by them. Under a neoliberal ethos the PBI reform was to abolish both the hated tax (AGRA) and the PBI itself and reopen it as an objective, official and professional agent outside the public sector. But the new, sudden reform was based on a concept of governability that sought full control of the government over the management, funds and personnel. Economics and governability intertwine, limiting the role of the gatekeepers in Israeli democracy.

3) National Basic Law-Jewish vs. Democratic?

In order to understand the breath of the struggle for identity politics, it is crucial to understand who is the "people" that the rightwing government promote, and how is it different than the "new Israelis" that were the key concept of the social protest that brought over 400,000 people to the streets in 2011. The third axis of the election which won Netanyahu his third term, and the most crucial of them all, is collective identity. The claim about governability is far from being a proceduralist one. Rather, it is ingrained in a deeply rooted different understanding of who is "the people" and what is the will of the people in the government's eye. One key case, in which this question unfolds, is the rise of the National Homeland from a marginal law put forward by Kadima member in 2011, to one of the main reasons for the dissolution of the 2013 government and a major tenant of the coalition guidelines of the Netanyahu regime since 2015. As in the PBI case, it is not necessarily that the end result was known in advance. Contradicting tracks that coexist in tension within the rightwing ideology pull 
and push to opposite ends with the ad hoc political constellation dictating the winner of the day. The national homeland law may be perceived from the same vernacular.

Avi Dichter, former director of the Shin Bet, currently the chair of the security committee as a Likud member, proposed in August 2011, together with other 39 MKs, a new "Basic Law: Israel—the Nation State of the Jewish People". The MKs—coming from Kadima, Likud backbenchers, Israel Betenu and the Jewish Home-did not know at the time who wrote the law proposal (though Dichter's desperate plea for Media, in view of the upcoming leadership struggle in Kadima, was well known). The main justification for the proposal was to hinder a binational state in Israel (Basic Law Proposal, 2011). The most striking thing about this law, is the priority order which it determines: the first article is called the Jewish State, stating that Israel in the homeland of the Jewish people and only the Jewish people has a right to a national state in Israel. The second article is called Democratic State, thinly stating that Israel is a democratic regime. Jewish first, democratic later. Jewish values, democratic procedures. This comes as no surprise when one discovers the original authors of the law: The Institute for Zionist Strategy, a settlers' NGO with vast connections to the rightwing parties. Dichter did not win the election for leader of Kadima and departed to the Likud. However, the national basic law has taken a fascinating independent history of its own.

Indeed, the elected leader of Kadima, Livni, requested Prof. Gavison, known for her position for a national democracy, to prepare the proposal for the law. Instead, Gavison wrote a report, explaining why this law should not be legislated. Gavison is also a former founder and chairperson of the Human Rights Association in Israel, but later a vocal speaker against the stronghold of the supreme court over politics, and an ardent supporter of Israel as a national democracy of the Jewish people, against the alternative "state of all its citizens" (MEDINAT KOL EZRACHYA) or a liberal democracy with no national supremacy. In her report she concludes that a national basic law should not be legislated by the Knesset, because it harms two out of the three foundational concepts of Israel-Judaism, democracy and human rights. Additionally, should such basic law be constituted, it would always be in a fundamental contradiction with the basic law of human rights, and all conflicts will end up in the supreme court, which would thus have more power-to which she objects (Gavison, 2014). Gavison lays out the problem: in most democratic constitutions, the national declarations are in the preamble; the constitution provides the bill of rights and institutional design. In Israel there is no constitution and hence no preamble. Gavison thus advices against the law and in the case that the Knesset rejects her recommendation, she suggests that a "Basic Law: Vision of the State" would be introduced to include the national-historical background and the shared values for which Israel stands. She adamantly rejects "Basic Law: National State", mainly due to the harm to the Arab minorities. 
However, those who were backbenchers in 2011, progressed in their power position to the front in 2013 government. In 2014 MK Shaked from the Jewish home and MK Elkin from the Likud national-religious heartland, proposed two versions of the law. Shaked-today the minister of justice and at the forefront of the ideological spear of the government-added in the second article, it addition to stating that Israel is a democratic regime, a second clause which states "Israel will be established on the foundations of liberty, justice and peace according to the vision of the Jewish prophets and committed to the personal rights of all its citizens as described in any basic law" (Basic Law Proposal, 2013). Shaked obviously sought to counter the critique but in her interpretation, the values of liberty, justice and peace are no longer universal values, but Jewish values of the prophets, and the rights accorded to the citizens are "personal rights"- not civic or political. In her famous speech Shaked as the Justice Minister argues:

In 2017 Israel, a state that its constitutional regime is composed of human rights, without any mention in its basic laws to her being the nation state of the Jewish people-Zionism has become the dead zone of its laws... Zionism should not continue-and I declare here, would not continue-to bow its head in front of the system of civic rights interpreted in a universal manner in a way that disconnects it from the protocols of the Knesset and the historical legislation we all know (Krasnety, 2017).

Namely, what Gavison feared, Shaked has hoped for: Changing the balance between human rights and the Jewishness of the states in its constitutional design: Jewish first, human rights later. The inner battle within the 2013 coalition produced a strange compromise: the ministers pressured to pass the law; Netanyahu offered a deal: the government would approve the more radical national basic law proposal forwarded by Elkin and Shaked, but once the PM office would forward a proposal of his own, they would support it. The legislation has passed the first vote 19 November 2014. Netanyahu has not yet-three years later-produced a rival proposal. However, his government is obliged, according to the coalition agreement, to establish a committee and all coalition partners are obliged to support its proposal.

On 18 September 2017, the committee met to prepare the law for first call in the Knesset-the majority of the critique suggested that equality is not part of this basic law (Yosef, 2017). Again: this is precisely the move the government sought-to move away from equality and put collective rights of the Jews first. Thus, changing the rules of the game is a profound mission of Netanyahu's regime, and the gradual process in which the Basic Law: National Jewish State transformed from Kadima to the Likud and its rightwing partners, and from the backbenchers to the forefront of the crucial ministers in Netanyahu's government-Elkin, Shaked and Levin being the ideological hardcore of changing the constitutional situation of Israel. This also substantiates why collective identity is at the heart of the political struggle for Israeli democracy. Some compromise versions where proposed by Kulanu but the committee has not yet reached a 
verdict and Netanyahu has not put forward any version different than the more extreme Shaked and Elkin proposals. Netanyahu however demanded that the Basic Law would pass the vote by summer 2018. A constitutional change is clearly at the heart of his government's mission, seeking to change the shared values and basic laws from the official position that perceives Israel as both democratic and Jewish to one which prioritize Jewish first and democratic second.

\section{Discussion: Rightwing Populist Ideology and the State of Democracy}

1) Conceptualizing Politics into Ideology.

The three case studies expose a complex reality in which ideology is shaped-and reshaped-in relation to actual political and social processes as well as evolves over time. The first case presented the instrumentalization of the Arab citizens of Israel as a trigger for dissociating the "we" and the "them". "Them"-creating an antagonist coalition of the Arabs, the post-Zionist Left and human rights organizations supported by foreign government as enemies of the people, against "us"- the national coalition of Netanyahu, the (Jewish) people, God and the IDF. Placing the Arab citizens in the midst of the Middle-East fundamental Islam and ISIS further pressed the point of the infatuation with the peace process and its deniability in an extremist, anti-Western Middle East. The security axis virtually transformed into collective identity axis through Netanyahu's manipulation of it. Yet, from this very extreme rightwing government came the most profound plan for economic recovery of the non-Jewish minorities of Israel. Apparently, a contradiction in terms, the neoliberal creed of the Likud party, placing economic growth above everything generated a strategy to count on the socialization of the Arabs in Israel-and particularly the Arab women-as a way of producing the next economic miracle. True, this was tamed by the emphasis that Netanyahu was determined to convey: police stations in Arab villages (tough on law enforcement) and no illegal construction (tough on order). These two focal points, including ruining houses that were built illegally, symbolized that the Netanyahu of the night of the 2015 election was still there, his hands firmly on the wheel: economic aid is conditioned on orderly behavior. "Will give will receive" as he likes calling it with the Palestinians in the negotiations. Neoliberalism and neoconservatism play hand in hand in the government's ideology, with its internal immanent contradictions.

The second case study, transforming the public media in Israel, started as a pure neoliberal-cum-new public management policy, and turned into a case of governability. The idea of cutting taxes and cutting government agencies by externalizing the IPB-closing it down and establishing a different, independent authority-sounds like a textbook neoliberal economics. The background to it - the politicization of the media, and the corruption which it brought-tell a fuller story. The switch from an independent IPB into the "we give money, we control" policy of the Netanyahu coalition, brought forward the key under- 
standing of democracy for this government. The sovereign people have chosen its representative leaders. These leaders profess to the will of the people. They therefore must be obeyed, and not criticized. The government is the key actor of democracy. Those maintaining the checks and balances are but hindrance to the positive action of the government. The courts, public media, universities, government officials-are all marked as enemies of the will of the people invested in the elected government. The president of Israel, Rivlin, in his speech at the Knesset's autumn 2017 opening session, referred to the Netanyahu government as generating an "all is political" revolution:

Majority rule-is the only ruler... a reality where "everything is political" is developing. The Media-political, the democratic institutions-all of them-from the professional bureaucracy to the state comptroller, political, the supreme-court-political, the security forces-political, is even the IDF, our defense force, political? All the country and its institutions-political. This revolution apparently attempts to tear, at last, the hypocrisy mask from the gatekeepers. In this revolution, the ruler is also the victim. "We shall show you what it is" this is the voice of this revolution, there is no more statehood, after us comes the flood (Rivlin, 2017).

This concept of democracy is of course fundamentally flowed: the parliament is the reflection of the citizens' sovereignty, not the government. The parliament represents all citizens-including Arabs, who compose $20 \%$ of Israel citizens, not just the Jewish people. The judicial system upholds the government and legislation accountable to principles of individual rights, the basis of democracy. Yet, the concept of majoritarian Jewish democracy, which is republican by virtue of thinking in terms of rights and obligations, and holding loyalty to state and people as part of these obligations-creates a highly problematic concept of democracy. Governability under this regime means governing without boundaries and without critics. A critic is by definition a traitor. The public media should therefore be controlled by the politicians-who represent the people-and act as its spokesperson. Criticism is a sin against the people's will so much so, that the president himself-at the heart of the Likud party only a few years ago-was signaled out as a non-patriotic traitor who joined the dark forces of the radical left.

The third case of the Basic Law of national Home manifests the idea of changing the rules of the game: it is not merely individual rights side by side with national rights; it is the superiority of the national rights over individual rights. Democracy is driven to its extreme, where it can hardly be maintained as a viable democracy, let alone a liberal democracy. Jewish peoplehood, governability and will of the people become dominant core concepts. Neoliberalism and neo-conservatism sit uneasily together. Populism is marked by a disdain against the ruling elites-the academia, the media, the art scene-as if the ruling elites is not the rightwing for over a generation now. 


\section{2) Conceptual Analysis.}

The conceptual morphology of the rightwing populist ideology thus comes to the fore. At the heart of the value-based worldview stands the sovereignty of the Jewish people in its state. Peoplehood is exclusively Jewish peoplehood, not Israel as the state of all its citizens. Not the concept of Israeliness that was forwarded by the 2011 social protest and became the founding rock of the left and center parties in the 2013 political system. There is a concept of formal civic rights, but this is part of a formal understanding of democracy-based on procedures rather than liberal values. Proceduralist democracy also translates into a technical understanding of governability. Governability is essentially about weakening the barriers that limit the ability of the elected government to rule. A populist understanding of the people assumes that the government fulfills the will of the Jewish majority. The minorities receive formal rights as individuals. The majority enjoys Jewification of the public sphere, Jewish and not Israeli interpretation of the symbolic and practical realm. This thick understanding is based on Jewish values as embedded in the bible and the Jewish (religious) tradition ever since. It anchors the right of the Jewish people to its land-the land of Israel as portrayed in the bible. It perceives the settlers as a continuation of the Zionist movement of redeeming the land of the fathers.

This concept of governability also means a profound weakening of the gate keepers-the justice system, the courts, the attorney general, the comptroller, the state officials, the police and the public media. All the crucial actors in a liberal democracy are seen as barriers and bureaucracy that are part of a left-liberal elite which sets to represent the old, established strata against the people and their lawful representatives in the government. Note that this majoritarian concept of democracy is hostile to the founding stones of liberal democracy and also weakens the power of the parliament vis-à-vis the government. The government is perceived as the key holder of the will of the people. The rights of the opposition are being limited and the critical function of inquisitive media is perceived as hostile leftist elites who act against the will of the populous.

The thick concepts of peoplehood are coupled with a thin concept of majoritarian democracy and a strong concept of governability. Neoconservatism is coupled with neoliberalism. The state does not know how to manage and lead and make profit-and therefore massive deregulation and privatization is in order. There is a minimal role for the state and a massive role for the elected government. Crucially, these concepts demand nothing short of changing the rules of the game: constitutional reform, economic reform, political reform.

\section{Conclusion}

The journey into the ideological make up of Israeli politics reveals a complex situation. First, far from signaling the end of ideology, or a populist opportunistic no-ideology, the Israeli rightwing professes a distinct and rigid ideology. Second, the ideology of the Netanyahu regime, analyzed through the case studies, suggests that a clear change of the rules of the game is sought, and being 
forwarded through legislation and policies. The key concepts in the government's ideology are governability, Jewishness, neoliberalism and neo-conservatism. Ideology encompasses internal contradictions and tensions between concepts and core ideas; nevertheless whether this populist republican ideology of the ruling coalition is just a different conceptualization of a majoritarian Jewish democracy, or whether democracy-human rights, public discourse, strong gate-keepers, checks and balances-is pushed out of the ideological design of the rightwing government altogether, and the consequences for Israeli democracy, remain open for interpretation. The ideological family of rightwing republican populism is doubtless closer to the extreme right than the center of the party system, and yet they are the ruling coalitions in some democracies today, Israel notwithstanding.

\section{References}

(2015). Governmental Activity for Economic Development of the Minority Populations in Israel (p. 922).

(2016). Coalition Agreement for the Establishment of the 34rd Government of the State of Israel between the Likud and Israel Beytenu.

Arian, A., Atmor, N., \& Hadar, Y. (2006). Auditing Israeli Democracy Changes in Israel's Political Party System: Dealignment or Realignment? Jerusalem: The Israel Democracy Institute.

Basic Law Proposal (2011). Israel the Nation State of the Jewish People.

Basic Law Proposal (2013). Israel the Nation State of the Jewish People.

Bell, D. (1960). The End of Ideology. Cambridge: Harvard University Press.

Caspit, B. (2018). The Netanyahu’s Years. New York: Dunne Books.

Cohen, O. (2017). Success and Failure. Davar1.

Comptroller, I. S. (2011). Yearly Report for 2010.

Dalton, R., \& Wattenberg, M. (2000). Parties without Partisans: Political Change in Advanced Industrial Democracies. Oxford: Oxford University Press.

Datal, L. (2015). Secret for Success Reveled: How Druze Villages Are Schooling Jewish Schools. The Marker.

Diskin, A. (2004). Israel. European Journal of Political Research, 43, 1033-1040. https://doi.org/10.1111/j.1475-6765.2004.00197.x

Downs, A. (1957). An Economic Theory of Democracy. Boston: Addison Wesle.

Finance, Mo. (2016). The Plan for the Icorpotating the Arab Society in the Economy.

Freeden, M. (1996). Ideologies and Political Theories: A Conceptual Approach. Oxford: Clarendon Press.

Gavison, R. E. (2014). Constitutional Anchoring of Israel's Vision. Jerusalem: The Minister of Justice.

Kellner, D. (2016). American Nightmare. Rotterdam: Sense Publishers.

Krasnety, E. (2017). Minister Shaked: "The Justice System Hollowed-Out Zionism”. Channel 20

Landes, R. (2014). Report of the Committee for Examining the Plans for Future Public Broadcasting in Israel. The Committee for Examining the Plans for Future Public Broadcasting in Israel. 
Lipset, S. M., \& Rokkan, S. (1967). Party Systems and Voters Alignment. New York, NY: Free Press.

Mair, P. (2013). Ruling the Void: The Hollowing of Western Democracy. Verso.

Malki, E. (2016). Miri Regev: "What's the Point of the Corporation if We Don't Control It". Calcalist.

Mudde, C. (2007). Populist Radical Right Parties in Europe. Cambridge: Cambridge University Press.

Myers-JDC-Brookdale (2015). The Arab Population in Israel: Facts and Figures.

Norris, P. (2010). Democratic Deficit: Critical Citizens Revisited. Cambridge: Cambridge University Press.

Oren, A. (2015). Netanyahu's "The Arabs Are Coming”-Not Incitement to Racism, Says AG. Ha'Aretz.

Rivlin, R. (2017). Speech from the President of the State of Israel for the Opening of the 4th Seating of the 20th Knesset. The 263th Meeting of the 20th Knesset. Words of the Knesset.

Segal, A. (2015). This Is How Netanyahu Won the Elections. Channel 2.

Shamir, M., \& Arian, A. (1999). Collective Identity and Electoral Competition in Israel. The American Political Science Review, 93, 265-277. https://doi.org/10.2307/2585395

Shamir, M., \& Rahat, G. (2017). Introduction. In M. Shamir, \& G. Rahat (Eds.), The Elections in Israel 2015 (pp. 1-18). New York, NY \& London: Taylor \& Francis. https://doi.org/10.1017/9781316481752.001

Shamir, M., Dvir-Gvirsman, S., \& Ventura, R. (2017). Taken Captive by the Collective Identity Cleavage: Left and Right in 2015 Elections. In M. Shamir, \& G. Rahat (Eds.), The Elections in Israel 2015 (pp. 139-164). New York, NY \& London: Taylor \& Francis.

Shamir, M., Ventura, R., Arian, A. et al. (2008). Kadima-Forward in Adealigned Party System. In A. Arian, \& M. Shamir (Eds.), The Elections in Israel 2006 (pp. 15-43). Jerusalem: The Israel Democracy Institute.

Simchon, A. (2016). Short Economic History of Israel. In E. Ben-Raphael, J. Schoeps, Y. Stenberg, \& O. Glöckner (Eds.), Handbook of Israel: Major Debates (pp. 378-388). Berlin: De Gruyter.

Smith, G. (1990). Core Persistence, System Change and the "People's Party". In P. Mair, \& G. Smith (Eds.), Understanding Party System Change in Western Europe (pp. 157-167). London: Frank Cass.

Talshir, G. (2015). “The New Israelis": From Social Protest to Political Parties. In M. Shamir (Ed.), The Elections in Israel 2013 (pp. 31-58). Tel Aviv: Transaction Publishers.

Thomassen, J. (1994). Empirical Research into Political Representation. In K. Jennings, \& T. Mann (Eds.), Elections at Home and Abroad (pp. 237-264). Michigan: Ann Arbor.

Toker, N. (2017a). "The Corporation Will Fire Only Those Who Misbehave”: The Supreme Court Justices Hint against Netanyahu. The Marker.

Toker, N. (2017b). Head of Broadcasting Corporation: "Politicians Asked Us to Hire Their Own People". The Marker.

Toker, N. (2018). Control the Media, of all Kinds (p. 2). The Marker.

Toker, N., \& Zerharia, T. (2017). Derei to Initiate the Closure of the Broadcasting Corporation; Netanyahu: "I'll Talk to Caklon about It". The Marker.

Van Dijk, T. (2011). Discourse Studies. Los Angeles: Sage.

Yosef, I. (2017). Gavison: The Nation Law Is the Law of Laws. News1. 